\author{
Review Article \\ www.ijrap.net
}

\title{
ETHNOPHARMACOLOGY, PHYTOCHEMISTRY AND PHARMACOLOGY OF AYURVEDIC PLANT HADJOD - CISSUS QUADRANGULARIS (L.)
}

Tanmoy Mukherjee ${ }^{1}$, Nabarun Saha ${ }^{2}$, Satadru Palbag ${ }^{3 *}$

${ }^{1}$ UG Scholar, Bengal Institute of Pharmaceutical sciences, Kalyani, Nadia, India

${ }^{2}$ R.M.O \& Clinical Tutor; Department of Orthopedics, NRSMCH, Kolkata, India

${ }^{3}$ Assistant Professor, Bengal Institute of Pharmaceutical sciences, SPLPIM Campus, Kalyani Nadia, India

Received on: 28/03/16 Revised on: 17/04/16 Accepted on: 12/05/16

\author{
*Corresponding author \\ E-mail: spalbagju@gmail.com
}

DOI: $10.7897 / 2277-4343.074138$

\begin{abstract}
Cissus quadranngularis L. is a ubiquitous plant of the vitaceae family and has multifaceted therapeutic use in the traditional system of medicine in India as well as other countries; it is also used as a nutritive element in several cuisines. It is commonly known as 'Hadjod' (bone-setter) in the native Indian language which highlights it effectiveness in fracture healing. Among other pharmacologic activities, its stem juice is indicated in menstrual disorder; dyspepsia, wound-healing, ariel parts of the plant have been reported to possess anti-microbial, anti-inflammatory, anti-tumor, hepatoprotective and gastro protective actions. This review article reveals that a wide range of novel phytochemical constituents has been isolated from this plant with diverse chemical properties. The current review deals with the enormous data that has been generated due to recent widespread research into the phytochemical, pharmacological aspect of this plant till December 2015 and also includes reports on its ethno pharmacology.
\end{abstract}

Keywords: Cissus quadrangularis, Ethnopharmacology, Phytochemistry, Pharmacology.

\section{INTRODUCTION}

According to W.H.O about $80 \%$ of world population depends on traditional system of medicine ${ }^{1}$. India has a very vast resource of indigenous plants and minerals which are an excellent source of therapeutic claim. One of such medicinal plant of India is Hadjod (Cissus quadranngularis L). The etymology of the local name signifies the plant's remarkable ability to cure bone fracture (Had bone, Jod $\sim$ setter). It's a rambling vine endemic to the tropical/warm regions of India, Sri-lanka, Malaysia, Java and West Africa. According to the authors there are two varieties of the plant(though the botanical source may be same).One of them possesses a very thin and two stem surfaces while the other one is quadrangular but very slim compared to original plant. It is thought to be a native of the Indian subcontinent and has now been imported into Brazil and the United States. The details of the plant is not described in three great compendium of Ayurveda, viz: Charaka Samhita, Sushruta Samhita and Ashtanga Sangraha but it is mentioned in the Ayurvedic lexicons over plants which are known as Nighantus. The Nighantus stressed the use of the plant in fracture healing and bone setting. Phytoconstituents of the plant is remarkable and support its several therapeutic activities apart from single bone reemineralization. Today's pharmacological study over Hadjod proves the ancient classical references of the plant and reestablishes the plant's potentiality to cure several diseases.

\section{Botany}

Cissus quadrangularis or 'Hadjod' as it is known in Hindi is a fleshy plant of the vitaceae family commonly found throughout India. The surface of the shrub is smooth glabrous buff coloured with a greenish tinge, the angular portion of the plant have a reddish-brown hue. Flowering occurs in the month of JuneDecember. Flowers are small, greenish-white bisexual tetramerous and occurs in umbellate cyme, opposite to the leaves, presence of 4-5 petals are observed which are imbricate, internodes measure 4-5 cm long and 1-2 cm thick with occasional tendril at nodes. Cup shaped calyx is short, entire and deciduous in nature. Roots are aerial and develop during the rainy season. It is a one seeded plant and seeds are ellipsoid or pyriform in shape. Its alternate, simple leaves are also thick and ovate with serrated margins.,3

\section{Ethnopharmacology}

The Plant Cissus quadrangularis is Known as 'Asthi Samharaha' in Sanskrit which literally means Pacification of bones, this name is good indicator of the bone-healing properties of the plant apart from that the plant is mentioned for various ailments in Ayurveda, according to Kirtikar and $\mathrm{Basu}^{3}$ the stem of the plant is hot, dry, sweetish, bitter, laxative, anthelmintic, aphrodisiac, stomachic and analgesic and used in blindness epilepsy and loss of appetite. In the Unani system of medicine, it is described as a bitter and is given internally and applied topically to bone fracture.

In Siddha medicine it is considered a tonic and analgesic, and is believed to help heal broken bones, The Garo tribe of Bangladesh have used Cissus quadrangularis as a medicinal plant for bone healing. The leaves of the young shoots of the plant are considered alternative and stomachic and their powder is given in digestive problems. The stem is antiscorbutic ${ }^{5}$, its paste is given in asthma and its juice is administered both internally and externally for the union of fractured bones. The juice of its shoots is beneficial in epistaxis when administered into the nostril; it is also used in otorrhea as an eardrop and in irregular menstruation.

The powder of the ashes of its shoots is administered internally in case of dyspepsia. ${ }^{6}$ Its root powder is also used to unite bone fractures and is considered to be as much effective as bone 
plaster. Besides its root powder is used orally in constipation and gout. ${ }^{7}$

\section{Phytochemistry}

Phytochemical screening of the plant has revealed the presence of iridoids, stilbene derivatives, sterols, triterpenes, alkaloids, fatty-acids, methyl esters, flavonoids, etc. ${ }^{\beta}$

Investigation on leaves revealed the presence of five known compounds including Ecosyl eicosanoate, Tetratriacotanol, Tetratriacontanoic acid, $\alpha \beta$-amyrin(a), $\beta$-sitosterol(b). Polyphenols such as Quercetin (m), Daidezein (c) and Genistein(f) has also been reported. ${ }^{8}$

Presence of Lupeol (g) has also been detected and it's melanin promoting activity(B16F10 Melanoma) has been also studied upon. ${ }^{9}$

Two new Iridoids; 6-0[2, 3-dimethoxy]-trans-cinnamoyl catalpol(o) and 6-0-meta-methoxy-benzozyl catalpol(p) along with a known Iridoid-Picroside-1(j) and Pallidol(h) were reported ${ }^{4}$. Three new marker constituents namely Onconer-7ene-3 alpha 21 beta-diol, $\delta$-Amyrin(d) and 3,3',4,4'tetrahydroxy biphenyl has also been found to be present in the aerial parts of the plant. ${ }^{10}$

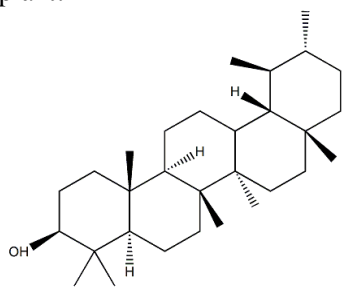

(a)

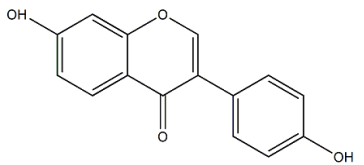

(c)

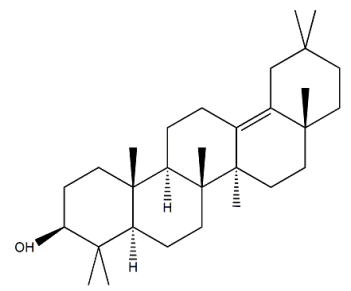

(d)

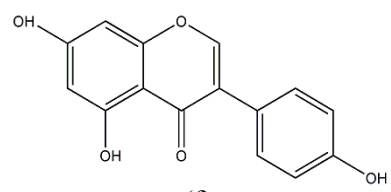

(f)
Recently seven new lipid compounds has been isolated from Cissus quadrangularis extract they are namely 4-hydroxy-2methyl-tricos-2-ene-22-one, 9-methyl-octadec-9-ene, Heptadecyl octadecanoate, Icosanyl icosanoate, 31-methyl-tritricontan-1-ol, 7-hydroxy-20-oxo deocosanyl cyclohexane and 31methyl triacontanoic acid.Taraxeryl acetate(n), Isopentacosanoic acid and freiedelan-3-one is also found to be present in CQ exract. ${ }^{11}$

Stilbene derivatives like Quadrangularin-A(k),-B(l),$\mathrm{C}$,Resveratrol(q) and Piceatannol(i) is also extracted from this plant. $^{12}$

Four new Dammarane type triterpenoids is also reported from this plant, this includes 24-methyl-dammara-20, 25-diene-3beta-yl-palmitate,24-methyl-dammara-20, 25-diene-3-beta-ylstearate, 24 methyl-dammara-2,20,25-triene-1-one,24-methyldammara-20, 25-diene-3 -one. ${ }^{13}$

Friedelin(e) which is a phytoestrogen found in Cissus quadrangularis extract has been implicated in the increase of A.L.P activity and increased rate of mineralization through estrogenic receptors. ${ }^{14}$

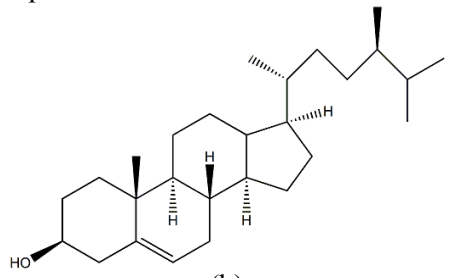

(b) 


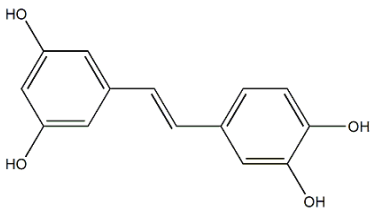

(i)

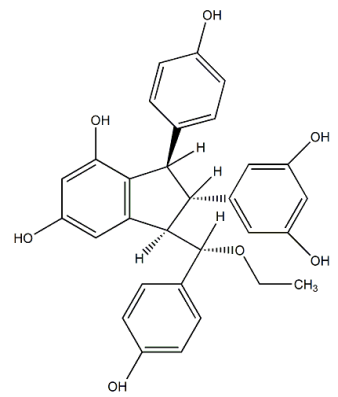

(1)

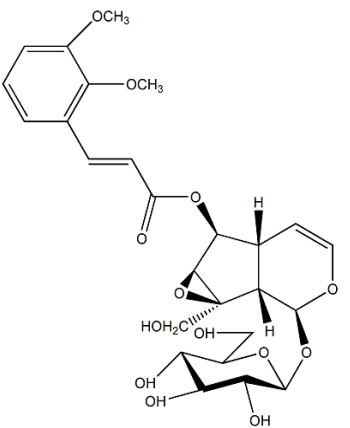

(o)

\section{Pharmacology}

Anti-osteoporotic activity: The main traditional use of Cissus quadrangularis is in the field of bone remineralization and bone fracture. Hence there are several studies that has already established the age old use of this plant in this particular area of interest. A study on petroleum ether extract revealed the effects of Cissus quadrangularis (C.Q) on bone cell proliferation and mineralization. The experiment was done by isolating bone marrow mesenchymal cells (MSC) of male Wister rats. The MSC were then kept in two separate media, the first group consisted of basal media [Dulbecco's Modified Eagle's Medium (DMEM) with $15 \%$ fetal bovine serum, $100 \mathrm{U} / \mathrm{ml}$ penicillin and $100 \mathrm{micro}$-gram $/ \mathrm{ml}$ streptomycin], the second one was composed of a osteogenic media (DMEM with 10\% fetal bovine serum,1 micro-Mole dexamethasone, 1 mili- Mole Glycerol phosphate, $0.05 \mathrm{mM}$ Ascorbic acid, $100 \mu \mathrm{g} / \mathrm{ml}$ penicillin and $100 \mu \mathrm{g} / \mathrm{ml}$ streptomycin). Both these group of MSC were allowed to differentiate with ad without addition of Petroleum ether extract of Cissus quadrangularis. The study concluded that groups treated with Cissus quadrangularis extract had a much higher proliferation rate (in ranges of 3-fold) and subsequent differentiation to Osteoblasts which was identified by using Alkaline Phosphatase(ALP) (an indicator for osteoblast activity as a bio-marker). The differentiation of MSC to osteoblasts was absent in groups not treated with the petroleum ether extract of the plant. Further studies revealed that groups when treated with petroleum ether extract have a very high rate of mineralization. ${ }^{15}$

Another study revealed the beneficial effects of the plant extract in the treatment of induced osteoporosis. Ovareictomized rats were taken for the particular study which simulated postmenopausal bone loss due to osteoporosis. ALP, and osteoporosis. The estimation of ALP and tartarate-resistant acid phosphatase (TRAP) expression was done by using dyeing and subsequent analysis using microscope and computer software which extrapolated intensity of the dyeing to concentration of bio-marker ALP and TRAP. The experiment concluded that ALP levels have increased while TRAP levels which is a widely accepted indicator for bone resorption through osteoclast function has decreased. Study of the femur morphology supported the data that bone loss has been decreased substantially. ${ }^{16}$

Anti-inflammatory activity: Study revealed the antiinflammatory activity of Cissus quadrangularis extract by measuring its ability to inhibit COX (Cyclo-oxgenase), 5-LOX (Lipo-oxygenase), TNF (Tissue necrosis Factor)- Alpha, etc. 
Active fraction of Cissus quadrangularis extract showed a $\mathrm{IC}_{50}$ value of $550 \mathrm{micro}$-gram $/ \mathrm{ml}$. Inflammatory effect of the active fraction was studied by pre-incubating RAW 264.7 cell in active fraction of various concentrations and assayed using MTT assay. Result showed effective reduction in COX, iNOS (Nitric oxide synthase) and TNF-Alpha levels in dose-dependent manner. ${ }^{17}$

Analgesic and anti-pyretic activity: Analgesic study and antipyretic studies of Cissus quadrangularis revealed that the plant is as potent as aspirin which was taken as standard in the treatment of acetic acid induced writhing in mice, formalin test and tail-flick test in rats. The plant is also effective in the treatment of yeast injection induced hyper-pyrexia. ${ }^{18}$

Anti-Oxidant activity: Both in-Vivo and in-Vitro analysis of anti-oxidant properties of Cissus quadrangularis were evaluated in several studies. In a particular study the In-Vitro studies were carried out using two methods- The first test of anti-oxidant activity was assessed through erythrocyte lipid peroxidation rate in which (Thiobarbituric acid reactive substance) TBARS formation was used as a marker and Butylated hydroxyl toluene(BHT) was used the reference drug. The second study incorporates the discoloration of 1,1-diphenyl-2-picrylhydrazyl radical(DPPH) where Catechin was used as the reference drug. In both the cases the antioxidant activity of Cissus quadrangularis extract was found to be almost on-par with reference drugs. In-vivo analysis for the anti-oxidant activity of Cissus quadrangularis was studied over $\mathrm{CCl}_{4}$ treated rats with several enzymes like Aspartate amino-transferase, Superoxide dismutase, catalase, Glutathione peroxidase was taken as biomarkers. The study revealed that the rats pretreated with Cissus Quadrangularis extract have lower level of these enzymes indicating the plant's antioxidant activity. ${ }^{19}$

Hepatoprotective activity: Hepatoprotective effects of Cissus quadrangularis extract was analyzed by using it in rats which had been previously administered Isoniazid in order to induce hepatotoxicity. Effectiveness of Cissus Quadrangular is extract was done monitoring levels of key bio-markers such as Aspartate transaminase (AST), Alanine transferase (ALT), Alkaline phosphatase (ALP) and bilirubin. Results obtained from the experiment and analysis of the liver of the sacrificed animal using ERBA diagnostic kits showed higher level of the aforementioned markers, additionally it was found that there is also a marked decrease in lipid peroxidation and increased antioxidant activities due to decreased Glutathione (GSH), Superoxide dismutase(SOD), Catalse (CAT) levels. ${ }^{20}$

Anti-diabetic activity: Anti diabetic property of Cissus quadrangularis was established in a study where dry powder of Cissus Quadrangular is, obtained through ethyl acetate extraction was administered to diabetic rats to study antidiabetic property of Cissus quadrangularis. Diabetes was induced in wister albino ratsby administering alloxan. The efficacy of Cissus quadrangularis was compared to Glibenclamide. The study revealed that that plasma glucose concentration taken after 72 hours showed promising antidiabetic activity which was found to be quite comparable to Glibenclamide. $^{21}$

Anti-tumour and cytotoxic activity: Cytotoxic studies of Cissus quadrangularis ethanolic and chloroform extract was validated both on HeLa and Vero cell lines in a study, the cell lines were maintained in minimal essential media in a humidified atmosphere. The $\mathrm{IC}_{50}$ value of extracts were found to be $62.5 \mu \mathrm{gm} / \mathrm{ml}$ and $125 \mu \mathrm{gm} / \mathrm{ml}$ for HeLa and Vero cell lines respectively. ${ }^{22}$
MTT assay of the isolated flavonoid fraction of the ethanolic extract of Cissus quadrangularis done in a separate study over MCF-7 cell lines revealed a promising $\mathrm{IC}_{50}(10 \mu \mathrm{gm} / \mathrm{ml})$ value for the flavonoid fraction. It was found to be within the $\mathrm{NCI}($ National cancer institute) category for anti -cancer agents and hence can be considered to possess potent cytotoxic action. $^{23}$

In a different anti-cancer study the phenolic contents obtained from Cissus quadrangularis extracts were subjected to an invitro model using A431(Skin epidermoid carcinoma)human cell line. Purified acetone fraction of the Cissus quadrangular extract exhibited potent anti-cancer activity with $\mathrm{GI}_{50}$ value being $4.8 \mu \mathrm{gm} / \mathrm{ml}^{24}$

In another literature the aqueous extract and ethanolic extract of the Cissus quadrangularis plant was studied for its cytotoxic activity against Dalton's ascitic lymphoma and Erlich ascitic induced carcinoma. The survival time of the test subjects treated with the extract increased to $72-76$ percent, compared to 96 percent in case of 5-fluro-uracil treatment. ${ }^{25}$

Anti-Viral activity: Anti-viral activity of partially purified methanolic extract of Cissus quadrangularis was established on both Herpes Simplex Virus(HSV)-1 and-2. Anti-viral activity of the plant activity was assayed using dye-uptake method. The result provided insight into potent anti-viral activity of Cissus quadrangularis. ${ }^{26}$

Anti-Bacterial activity: Anti-bacterial activity of Cissus quadrangularis extract was studied using agar-well diffusion method where tetracycline was used as the reference drug. The study revealed that the ethyl acetate extract was the most effective and that gram-positive bacteria was the most susceptible although gram negative bacteria showed high level of resistance. ${ }^{27}$

In another literature opportunities to develop new antibiotics from Cissus quadrangularis was discussed upon and effect of various types of Cissus quadrangularis extracts over several classes of bacteria is analyzed with result concluding that the ethyl acetate fraction of CQ extract being the most effective against Xanthomonas campestris and that the inhibitory concentration of the several fraction of CQ extract against the Seven different classes of bacteria examined ranges between 256- $1024 \mu \mathrm{gm} / \mathrm{ml}^{28}$

Anti-Fungal activity: Anti-fungal activity of Cissus quadrangularis extract, was established by comparing its activity to fluconazole which was taken a standard drug. The research was performed using standard agar-well diffusion method and the activity was quantified by measuring the diameter of the zone of inhibition formed on the surface of Petridishes. The result revealed the effect of Cissus quadrangularis extract against fungal activity and it was found out that diethyl ether extract exhibited promising activity against Aspergillus flavus. ${ }^{29}$

Anti-haemorrhoidal activity: Anti-haemorrhoidal properties of Cissus quadrangularis extract was studied by measuring the venular activity of its extract on vascular smooth muscles of human umbilical vein. Results showed that the contraction occurring in extract treated smooth muscles was equal to the contraction achieved when treated with standard drug 'Daflone'. ${ }^{30}$

Anti-convulsant and sedative activity: Anti-convulsant effect of Cissus quadrangularis was established in a research by using 
aqueous extract of the plant. The effectiveness was gauged using the extract in several anti-convulsant tests such as N-methyl-Daspartate (NMDA) test, Maximal electroshock (MES) test, Strychnine (STR) test, Pentylenetetrazole (PTZ) test, Isonicotinic hydrazide acid (ISH) test. 'Clonazepam' was used as standard drug in PTZ and STR test while diazepam was used in INH and MES induced seizures and D-AP7 was used as standard reference drug in NMDA seizures. Sedative activity of Cissus quadrangularis was also studied by measuring the effect of its extract on prolonging diazepam induced sleep and as a result the extract prolonged the sleep duration. ${ }^{31}$

Anti-helminthic activity: Anti-helminthic activity of Cissus quadrangularis were revealed using stem extract of the plant against earthworms in a study. The effectiveness was measured by the time required by the extract to induce paralysis or cause death in test subjects. ${ }^{32}$

Anti-ulcerative and gastroprotective activity:Anti-ulcerative studies were revealed by assessing the effect of Cissus quadrangularis extract on enzyme $\mathrm{H}+-\mathrm{K}+$-ATPase which is deemed responsible for producing acidity in stomach. Results showed potential inhibition of proton-pump activity and in-vitro studies indicated that the methanolic extract potently reduced hydrolysis of ATP by gastric ATPase. The activity of the extract was comparable to the standard drug (Omeprazole) taken. ${ }^{33}$ Study also revealed the gastroprotective activity of the plant in aspirin-induced ulcerogenesis in pyloric-ligated rat models. Gastroprotective activity was established by measuring gastric juice output, adherent amount of gastric mucosa, Non-Protein sulphydryl groups (NPSH) and by histopathological studies. Results showed that Cissus quadrangularis pre-treated rats had higher NPSH concentration, higher gastric mucosa protection and lower acid output compared to un-treated rats. ${ }^{34}$

Anti-obesity and anorexiant activity: Research revealed antiobesity activities of the plant. A study was performed using a Cissus quadrangularis formulation known as Cylaris. The study had a double-blind, placebo-control design. Results showed test subjects had decreased waist circumference, Body Mass Index (B.M.I), reduced serum lipid levels (LDL-cholesterol, triglyceride and total cholesterol), lower C-reactive protein count and fasting blood glucose ${ }^{35}$. It was also concluded that the extract might have anorexiant activity. This conclusion was arrived through an empirical approach after observation of increased serotonin levels in blood. ${ }^{36}$

\section{CONCLUSION}

The plant Cissus quadrangularis L. holds a great deal of potential as a choice in alternative therapies for osteopathic disorders and weight-loss. The acceptance of patent Cylaris ${ }^{\mathbb{B}}$ for weight-loss formulation containing Cissus quadrangularis L. extract further shows the effectiveness of therapies from plant origin. The anti-tumour, anti-microbial, anti-inflammatory, antioxidant activity of the plant shows great promise with the usual advantage of being almost free from high toxicity observed in contemporary drugs.

More detailed study of ethno-pharmacological effects of plants should be undertaken with proper scientific fore-knowledge, detailed documentation should be done in order to open new avenues of application of traditional medicinal science into devising therapeutics for present day problems.

The next level of research with state-of-the art instrumental analysis along with laboratory investigations should be done to understand the mechanism of action of the therapeutically active metabolites and the formulation or individual compounds should be trialed clinically to formulate new drugs and mode of therapies.

\section{REFERENCES}

1. Satadru Palbag, Kuntal Pal, Dhiman Saha, M.K. Nandi, B.K.De, D.N.S. Gautam. Pharmaceutics, ethnopharmacology, chemistry and pharmacology of Ayurvedic marine drugs: A review. Int. J. Res. Ayurveda Pharm. 2013;4(3):437-442 http://dx.doi.org/10.7897/22774343.04326

2. Shah, Unnati. Cissus quadrangularis L: Phytochemicals, Traditional Uses and Pharmacological activities-A Review. Int J of Pharmacy and Pharm Sci 2011): 41-4.

3. Sen, Monokesh Kumer, and Biplab Kumar Dash. A review on phytochemical and pharmacological aspects of Cissus quadrangularis L. International Journal of Green Pharmacy 2012;6.3: 169 .

4. Kirtikar, Kanhoba Ranchoddas, and Baman Das Basu. Indian medicinal plants. Indian Medicinal Plants. (1918).

5. Chatterjee, A. and S. C. Prakashi. "Vol. III." The Treatise on Indian Medicinal Plants (1994): 173-174.

6. Kumbhojkar M.S. et al., Ethanobotany of Cissus quadrangularis Linn. from India., Ethanobotany, 1991;3:2125.

7. Singh, K. K. and J. K. Maheshwari. Traditional phytotherapy amongst the tribals of Varanasi District. J. Econ. Taxon. Bot 1983;4: 829-838.

8. Singh, Geetu, Preeti Rawat, and Rakesh Maurya. Constituents of Cissus quadrangularis. Natural product research 2007;21.6: 522-528. http://dx.doi.org/10.1080 $/ 14786410601130471$

9. Rao GV, Annamalai T, Mukhopadhyay T, Madhavi MSL. Chemical Constituents and Melanin Promotion activity of Cissus quadrangularis Linn. Res.J.chem.sci., 2011;1(2):2529

10. Mehta, Manisha, Navneet Kaur, and K. K. Bhutani. Determination of marker constituents from Cissus quadrangularis Linn. and their quantitation by HPTLC and HPLC. Phytochemical Analysis 2001;12.2: 91-95. http://dx.doi.org/10.1002/pca.569

11. Gupta, Madan M., and Ram K. Verma. Lipid constituents of Cissus quadrangularis. Phytochemistry 1991;30.3: 875-878. http://dx.doi.org/10.1016/0031-9422(91)85270-A

12. Adesanya, Saburi A., et al. Stilbene derivatives from Cissus quadrangularis. Journal of Natural Products 1999;62.12: 1694-1695. http://dx.doi.org/10.1021/np9902744

13. Pathomwichaiwat, Thanika, et al. Alkaline phosphatase activity-guided isolation of active compounds and new dammarane-type triterpenes from Cissus quadrangularis hexane extract. Journal of ethnopharmacology 2015;160: 52-60. http://dx.doi.org/10.1016/j.jep.2014.11.026

14. Aswar, Urmila M., et al. Estrogenic activity of friedelin rich fraction (IND-HE) separated from Cissus quadrangularis and its effect on female sexual function. Pharmacognosy research 2010;2.3: 138 .

15. Potu, Bhagath Kumar, et al. Petroleum ether extract of Cissus quadrangularis (Linn.) enhances bone marrow mesenchymal stem cell proliferation and facilitates

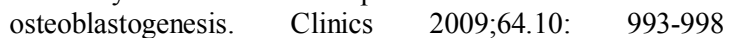
http://dx.doi.org/10.1590/S1807-59322009001000010

16. Potu, Bhagath K., et al. Evidence-based assessment of antiosteoporotic activity of petroleum-ether extract of Cissus quadrangularis Linn. on ovariectomy-induced osteoporosis. Upsala journal of medical sciences 2009;114.3: 140-148. http://dx.doi.org/10.1080/03009730902891784 
17. Bhujade, Arti M., et al. Evaluation of Cissus quadrangularis extracts as an inhibitor of COX, 5-LOX, and proinflammatory mediators. Journal of ethnopharmacology 2012;141.3: 989-996. http://dx.doi.org /10.1016/j.jep.2012.03.044

18. Vijay, Priyanka, and Rekha Vijayvergia. Analgesic, antiinflammatory and antipyretic activity of Cissus quadrangularis. Journal of Pharmaceutical Science and Technology 2010;2.1: 111-118.)

19. Jainu, Mallika, and CS Shyamala Devi. In vitro and in vivo evaluation of free radical scavenging potential of Cissus quadrangularis. African Journal of Biomedical Research 2006;8.2: 95-99. http://dx.doi.org/10.4314/ajbr.v8i2.35768

20. Swamy, AHM Viswanatha, et al. Evaluation of hepatoprotective activity of Cissus quadrangularis stem extract against isoniazid-induced liver damage in rats. Indian journal of pharmacology 2010;42.6: 397.

21. Srivastava, Anuj K., et al. Antidiabetic activity of the stem extracts of Cissus quadrangularis Linn. Journal of Pharmacy Research 2011;4.11: 3873-3874.

22. Dwivedi A, Seethalakshmi I and Sharmila D. Anti-cancer properties of Cissus quadrangularis. J. Chem. Pharm. Res., 2013; 5(5):135-139

23. Vijayalakshmi, A., et al. In Vitro Antioxidant and Anticancer Activity of Flavonoid Fraction from the Aerial Parts of Cissus quadrangularis Linn. against Human Breast Carcinoma Cell Lines. Journal of Chemistry 2013 http://dx.doi.org/10.1155/2013/150675

24. Bhujade, Arti, et al. Induction of apoptosis in A431 skin cancer cells by Cissus quadrangularis Linn stem extract by altering $\mathrm{Bax}-\mathrm{Bcl}-2$ ratio, release of cytochrome $\mathrm{c}$ from mitochondria and PARP cleavage. Food \& function 2013;4.2: 338-346. http://dx.doi.org/10.1039/C2FO30167A

25. Nalini G., et al. Evaluation of Anti-tumour activity of Cissus quadrangularis Linn against Dalton's ascitic lymphoma and Erlich ascitic induced carcinoma in mice. Int. J. Pharm. Sci. Rev. Res 2011;8: 75-79.

26. Balasubramaniana, P., et al. Antiviral activity of ancient system of ayurvedic medicinal plant Cissus quadrangularis L.(Vitaceae). Journal of basic and clinical pharmacy 2010;1.001: 37-40.

27. Kashikar, N. D., and Indu George. Antibacterial activity of Cissus quadrangularis Linn. Indian journal of pharmaceutical sciences 2006;68.2: 245 .
28. Sen MK, Faruquee HM, Mamun-or-Rashid ANM., Antibacterial activity of Cissus quadrangularis stem: a preliminary in vitro effort to develop antibiotic, Saarbrucken (Germany): Lap-Lambert Academic Publishing; 2012. P.24-7

29. Chidambara Murthy, K. N., et al. Antioxidant and antimicrobial activity of Cissus quadrangularis L. Journal of medicinal food 2003;6.2: 99-105. http://dx.doi.org $/ 10.1089 / 109662003322233495$

30. Panthong, Ampai, et al. Analgesic, anti-inflammatory and venotonic effects of Cissus quadrangularis Linn. Journal of ethnopharmacology 2007;110.2: 264-270. http://dx.doi.org/ 10.1016/j.jep.2006.09.018

31. Bum, E. Ngo, et al. The anticonvulsant and sedative properties of stems of Cissus quadrangularis in mice. African Journal of Pharmacy and Pharmacology 2008;2.3: 042-047.

32. Malviya, N., et al. Anthelmintic activity of Cissus quadrangularis Linn. Journal of Current Research in Ayurvedic and Pharmaceutical Sciences 2011;1.02

33. Yadav, Priyanka, Aditya Ganeshpurkar, and Gopal Rai. In vitro $\mathrm{H}+-\mathrm{K}+$ ATPase inhibitory potential of methanolic extract of Cissus quadrangularis Linn. Pharmacognosy research 2012;4.2: 123.

34. Jainu, Mallika, K. Vijai Mohan, and CS Shyamala Devi. Gastroprotective effect of Cissus quadrangularis extract in rats with experimentally induced ulcer. Indian Journal of Medical Research 2006;123.6: 799.

35. Oben, Julius E., et al. The use of a Cissus quadrangularis/Irvingia gabonensis combination in the management of weight loss: a double-blind placebocontrolled study. Lipids in health and disease 2008;7.1: 1.

36. Oben, Julius E., et al. The effect of Cissus quadrangularis (CQR-300) and a Cissus formulation (CORE) on obesity and obesity-induced oxidative stress. Lipids in Health and Disease 2007;6.1: 1

\section{Cite this article as:}

Tanmoy Mukherjee, Nabarun Saha, Satadru Palbag. Ethnopharmacology, phytochemistry and pharmacology of Ayurvedic plant Hadjod - Cissus Quadrangularis (L.). Int. J. Res. Ayurveda Pharm. Jul - Aug 2016;7(4):78-83 http://dx.doi.org/10.7897/2277-4343.074138

Disclaimer: IJRAP is solely owned by Moksha Publishing House - A non-profit publishing house, dedicated to publish quality research, while every effort has been taken to verify the accuracy of the content published in our Journal. IJRAP cannot accept any responsibility or liability for the site content and articles published. The views expressed in articles by our contributing authors are not necessarily those of IJRAP editor or editorial board members. 